\title{
Enhancing the spontaneous imbibition rate of water in oil-wet dolomite rocks through boosting a wettability alteration process using carbonated smart brines
}

\author{
Ehsan Ghandi ${ }^{1,2} \cdot$ Rafat Parsaei $^{2} \cdot$ Masoud Riazi $^{1,2}$
}

Received: 30 October 2018 / Published online: 22 July 2019

(c) The Author(s) 2019

\begin{abstract}
Most fractured carbonate oil reservoirs have oil-wet rocks. Therefore, the process of imbibing water from the fractures into the matrix is usually poor or basically does not exist due to negative capillary pressure. To achieve appropriate ultimate oil recovery in these reservoirs, a water-based enhanced oil recovery method must be capable of altering the wettability of matrix blocks. Previous studies showed that carbonated water can alter wettability of carbonate oil-wet rocks toward less oil-wet or neutral wettability conditions, but the degree of modification is not high enough to allow water to imbibe spontaneously into the matrix blocks at an effective rate. In this study, we manipulated carbonated brine chemistry to enhance its wettability alteration features and hence to improve water imbibition rate and ultimate oil recovery upon spontaneous imbibition in dolomite rocks. First, the contact angle and interfacial tension (IFT) of brine/crude oil systems were measured for several synthetic brine samples with different compositions. Thereafter, two solutions with a significant difference in WAI (wettability alteration index) but approximately equal brine/oil IFT were chosen for spontaneous imbibition experiments. In the next step, spontaneous imbibition experiments at ambient and high pressures were conducted to evaluate the ability of carbonated smart water in enhancing the spontaneous imbibition rate and ultimate oil recovery in dolomite rocks. Experimental results showed that an appropriate adjustment of the imbibition brine (i.e., carbonated smart water) chemistry improves imbibition rate of carbonated water in oil-wet dolomite rocks as well as the ultimate oil recovery.
\end{abstract}

Keywords Spontaneous imbibition · Carbonated smart water $\cdot$ Wettability alteration $\cdot$ Enhanced oil recovery $\cdot$ Dolomite rocks

\section{Introduction}

Reservoir rock in naturally fractured oil reservoirs consists of two regions with different permeabilities, namely matrix blocks and the fracture network. Oil recovery in these reservoirs strongly depends on the interaction between high conductive fractures and low conductive matrix blocks (Nelson 2001; Haugen 2010; Sahimi 2011).

Edited by Yan-Hua Sun

Rafat Parsaei

rafatparsaei@gmail.com; rparsaei@shirazu.ac.ir

1 Enhanced Oil Recovery (EOR) Research Centre, IOR/ EOR Research Institute, School of Chemical and Petroleum Engineering, Shiraz University, Shiraz, Iran

2 Department of Petroleum Engineering, School of Chemical and Petroleum Engineering, Shiraz University, Shiraz, Iran
Three major forces control the drainage of oil from matrix blocks: capillary force, gravity force, and viscous force. During waterflooding, injection water tends to flow quickly into the fractures and bypass the matrix blocks. Preferential flow of water through the fracture network causes a limited differential pressure across the reservoir that results in weak viscous forces for oil production. This leads to poor sweep efficiency and low oil recovery (Guo et al. 1998; Narr et al. 2006; Seyyedi and Sohrabi 2015). However, the two other forces, i.e., gravity and capillary, could be effective depending on the properties of the rock and fluids (i.e., the injection water and the reservoir oil) such as wettability of the rock, water/oil IFT, and the density difference between the displacing and displaced fluids.

In water-wet fractured reservoirs, water is the wetting phase; therefore, the capillary force would be a productive force to bring water spontaneously into the matrix (i.e., spontaneous imbibition) and expel the oil from the matrix 
into the fracture network. In such reservoirs, if there is a high-pressure high-rate water injection or a strong aquifer, the matrix oil could also, to some extent, be produced by force imbibition.

In oil-wet naturally fractured reservoirs, water is the nonwetting phase; therefore, the capillary force would be an unproductive force. However, gravity and to some extent viscous forces can be effective in oil production from matrix blocks. The lower the capillary force is, the more oil will be produced from the matrix. In addition, when an oil-wet reservoir is subjected to waterflooding and/or in the presence of a strong supporting aquifer, the mechanism of force imbibition would drive out the oil from the matrix blocks into the fracture network.

Previous field studies revealed that the process of imbibing water from the fractures into the matrix is one of the main oil recovery mechanisms in naturally fractured reservoirs (Bourbiaux and Kalaydjian 1990; Hirasaki and Zhang 2004; Narr et al. 2006). Imbibition, which is assisted by capillary and gravity forces, is known as a slow process. For naturally fractured oil reservoirs in which matrix oil is mainly produced by an imbibition mechanism, oil production is small because of the oil-wet nature of matrix blocks (Bourbiaux and Kalaydjian 1990; Babadagli 2003; Narr et al. 2006). In such reservoirs, water spontaneous imbibition is extremely slow or does not occur because of negative capillary pressure. However, force imbibition, if it exists, and/or gravity drainage, if the size of matrix blocks is appropriately high, would cause an improvement in oil production (Hirasaki and Zhang 2004). Therefore, for those oil-wet naturally fractured reservoirs where there is not enough pressure gradient across the matrix blocks to cause force imbibition of water into the matrix or viscous displacement of matrix oil, and also there is not enough gravity force to expel oil from matrix blocks, it would be necessary to alter the wettability of the matrix rock into a water-wet condition in order to improve the spontaneous imbibition rate. Hence, during a water-based EOR process in naturally fractured oil reservoirs with oil-wet rocks, injection water should be able to alter the rock wettability to water-wet conditions to achieve an appropriate ultimate oil recovery.

Wettability alteration of rock surfaces toward water-wet conditions would increase capillary forces, and injection water would imbibe more quickly into the rock (Standnes and Austad 2000a, b; Hirasaki and Zhang 2004; Meng et al. 2018; Pal et al. 2018).

The effectiveness of carbonated water (CW) in improving the water spontaneous imbibition rate and oil recovery in sandstone and limestone rocks has been shown in several studies (Grape 1990; Perez et al. 1992; Sohrabi et al. 2008, 2009, 2011; Fjelde et al. 2011; Seyyedi and Sohrabi 2015). According to these studies, the main mechanisms through which carbonated water enhances oil recovery in carbonate rocks are: (1) wettability alteration which occurs due to the synergic effect of mineral dissolution and potential determining ions, (2) oil swelling, (3) oil viscosity reduction, and (4) oil/brine IFT reduction.

It has been proven previously that the carbonated water is capable of dissolving limestone and dolomite minerals and detaching the oil aggregates from rock surfaces which leads to changes in wettability of carbonate rocks from oilwet to neutral conditions (Shiraki and Dunn 2000; Oelkers et al. 2008; Seyyedi et al. 2015; Abbaszadeh et al. 2016). However, wettability alteration toward neutral is not enough to achieve the proper rate of water spontaneous imbibition.

In recent years, there has been growing interest in smart water injection as an effective method in wettability alteration and improving spontaneous imbibition rate. Smart water is a brine with modified composition that changes the interfacial properties of the fluids and rock-fluid interfaces. Wettability altered by smart water is described as a symbiotic interaction between the potential determining ions $\mathrm{Ca}^{2+}, \mathrm{Mg}^{2+}$, and $\mathrm{SO}_{4}{ }^{2-}$ and the adsorbed carboxylic organic materials on the carbonate surface (Fathi et al. 2012; Shariatpanahi et al. 2016). This mechanism of wettability alteration has been previously observed in chalk, limestone and dolomite cores (Strand et al. 2006; Zhang et al. 2007; Fathi et al. 2010; Shariatpanahi et al. 2016).

Beside the wettability alteration aspect of smart water, it does not reduce water-oil interfacial tension significantly (Manshad et al. 2016), which is imperative for having a strong capillary force and as a result an effective rate of spontaneous imbibition of water into the matrix.

In this study, we made an attempt to investigate the potential of smart water for improving the wettability alteration feature of carbonated water to enhance its spontaneous imbibition rate in dolomite rocks. To achieve this purpose, first, the contact angle and interfacial tension (IFT) of crude oil/ brine systems were measured for several synthetic brine samples with different compositions. The compositions of the solutions were determined so that they contained all the important divalent ions for wettability alteration which are commonly found in injection brines (e.g., $\mathrm{Ca}^{2+}, \mathrm{Mg}^{2+}$, and $\mathrm{SO}_{4}{ }^{2-}$ ). Thereafter, two solutions with a significant difference in WAI (wettability alteration index) but approximately equal brine/oil IFT were chosen as imbibing solutions to investigate the effect of wettability alteration on spontaneous imbibition in the same IFTs. In the next step, spontaneous imbibition experiments at ambient pressure and high pressure were conducted to evaluate the ability of carbonated smart water in enhancing spontaneous imbibition rate and the ultimate oil recovery in dolomite rocks. 
Table 1 Properties of the utilized crude oil at atmospheric pressure and $75^{\circ} \mathrm{F}$

\begin{tabular}{lllllll}
\hline Density, g/cm & Viscosity, $\mathrm{cP}$ & API gravity, ${ }^{\circ} \mathrm{API}$ & \multicolumn{4}{l}{ SARA composition, wt\% } \\
\cline { 4 - 7 } & & & Saturates & Aromatics & Resins & Asphaltenes \\
\hline 0.9376 & 97 & 19.54 & 43.5 & 35.6 & 12.9 & 8.0 \\
\hline
\end{tabular}

Table 2 Composition of the formation brine and the Persian Gulf (PG) water

\begin{tabular}{|c|c|c|c|c|c|c|c|}
\hline \multirow[t]{2}{*}{ Fluid } & \multicolumn{6}{|c|}{ Composition, ppm } & \multirow{2}{*}{$\begin{array}{l}\text { Total dissolved } \\
\text { solids (TDS), } \\
\text { ppm }\end{array}$} \\
\hline & $\mathrm{Na}^{+}$and $\mathrm{K}^{+}$ & $\mathrm{Cl}^{-}$ & $\mathrm{Ca}^{2+}$ & $\mathrm{Mg}^{2+}$ & $\mathrm{SO}_{4}{ }^{2-}$ & $\mathrm{HCO}_{3}^{-}$ & \\
\hline Synthetic formation brine & 30,262 & 57,317 & 3317 & 1935 & 853 & 37 & 93,721 \\
\hline Persian Gulf (PG) water & 14,544 & 23,000 & 520 & 1500 & 3100 & 24 & 41,359 \\
\hline
\end{tabular}

\section{Materials and methods}

\subsection{Fluid properties}

In this study, crude oil used was obtained from an Iranian oil field. Table 1 lists its physical properties and the results of SARA (saturates, aromatics, resins, and asphaltenes) analysis.

Synthetic brine with a $\mathrm{pH}$ of 5.9 was used as the formation water for saturating all the core plugs used in this study. The brine was prepared to match the composition of the formation brine of the oil field from where the crude oil sample was taken. Table 2 shows the composition of the synthetic formation brine.

Different imbibing brine solutions (i.e., smart solutions) used in this study were prepared by dissolving $\mathrm{MgSO}_{4}$, $\mathrm{CaCl}_{2}$, and $\mathrm{NaCl}$ in distilled water based on the designed concentrations as will be explained in Sect. 2.3.1. For comparison, we also used Persian Gulf (PG) water with a $\mathrm{pH}$ of 6.3 as the imbibing brine in several spontaneous imbibition experiments. Table 2 shows the composition of the utilized PG water. Carbonated solutions were then prepared by dissolving carbon dioxide gas in smart water and seawater at a high pressure using the procedure described in Sect. 2.3.4.

\subsection{Core properties}

Several core plugs, taken from a carbonate outcrop rock, were used for ambient and high-pressure imbibition experiments and also for preparing thin sections utilized in contact angle measurements. As shown in Table 3 and Fig. 1, the X-ray diffraction (XRD) analysis of this rock shows that about $98 \%$ of the rock was dolomite $\left(\mathrm{CaMg}\left(\mathrm{CO}_{3}\right)_{2}\right)$.
Table 3 Results of X-ray diffraction analysis of the rock sample using X'Pert 3.0 software

\begin{tabular}{lll}
\hline Compound name & Chemical formula & $\begin{array}{l}\text { Approximate } \\
\text { quantity, wt } \%\end{array}$ \\
\hline Dolomite & $\mathrm{Ca}_{3.00} \mathrm{Mg}_{3.00} \mathrm{C}_{6.00} \mathrm{O}_{18.00}$ & 98 \\
Magnesite & $\mathrm{Mg}_{3.00} \mathrm{Cd}_{3.00} \mathrm{C}_{6.00} \mathrm{O}_{18.00}$ & 2 \\
\hline
\end{tabular}

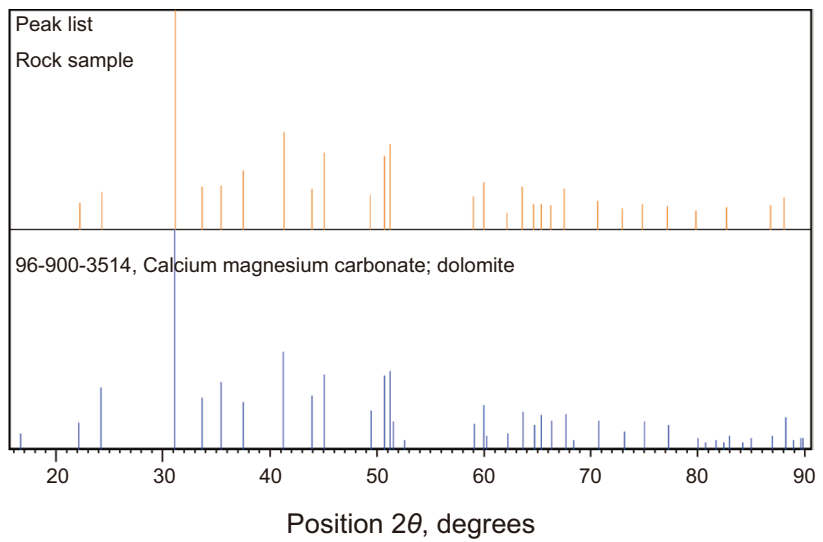

Fig. 1 Comparison of diffraction peaks of the rock sample and the standard dolomite. The XRD tests show that the rock is very largely dolomite

Table 4 shows the physical properties and dimensions of the core plugs used in atmospheric and high-pressure imbibition experiments. The porosity and permeability values of the core plugs were measured using a helium gas expansion porosimeter (GREBE 32351, VINCI, France) and a gas permeameter (Coreval 700, VINCI, France). In Table 4, the residual brine saturation after oil flooding, $S_{\mathrm{wi}}$, is also reported. 
Table 4 Properties of the core plugs

\begin{tabular}{|c|c|c|c|c|c|c|c|}
\hline Core plug ID & Experiment ID & Length, mm & Diameter, mm & Porosity, $\%$ & $\begin{array}{l}\text { Absolute perme- } \\
\text { ability, mD }\end{array}$ & Pore volume, $\mathrm{mm}^{3}$ & $S_{\mathrm{wi}}, \%$ \\
\hline $\mathrm{C}_{1}$ & $\mathrm{~A}_{1}^{*}$ & 53.34 & 38.35 & 18.03 & 26 & 78,448 & 19.3 \\
\hline $\mathrm{C}_{2}$ & $\mathrm{~A}_{2}$ & 49.53 & 38.61 & 19.13 & 32 & 73,835 & 23.3 \\
\hline $\mathrm{C}_{3}$ & $\mathrm{~A}_{3}$ & 50.29 & 38.10 & 18.27 & 26 & 73,001 & 22.4 \\
\hline $\mathrm{C}_{4}$ & $\mathrm{~A}_{4}$ & 51.56 & 38.12 & 20.61 & 29 & 74,923 & 24.7 \\
\hline $\mathrm{C}_{5}$ & $\mathrm{~A}_{5}$ & 50.55 & 38.58 & 19.05 & 24 & 75,239 & 33.1 \\
\hline $\mathrm{C}_{6}$ & $\mathrm{H}_{1}^{* *}$ & 51.54 & 38.60 & 22.81 & 31 & 76,792 & 27.3 \\
\hline $\mathrm{C}_{7}$ & $\mathrm{H}_{2}$ & 51.31 & 38.36 & 23.04 & 34 & 75,502 & 31.3 \\
\hline $\mathrm{C}_{8}$ & $\mathrm{H}_{3}$ & 51.26 & 38.44 & 20.42 & 28 & 75,743 & 29.5 \\
\hline $\mathrm{C}_{9}$ & $\mathrm{H}_{4}$ & 52.07 & 38.23 & 21.61 & 30 & 76,102 & 32.3 \\
\hline
\end{tabular}

*A: atmospheric spontaneous imbibition experiments $* * \mathrm{H}$ : high-pressure spontaneous imbibition experiments

\subsection{Methodology}

\subsubsection{Test design and solution preparation}

A key factor for analyzing the effect of different variables and investigating their interactive effect in an experimental study is to design the experimental conditions properly. Experimental design techniques offer a smaller number of experiments compared to the full factorial design. This is effective in reducing both the experimental time and cost. In this work, Design Expert software (version 7.0, Stat-Ease Inc.) was employed to determine the experimental conditions for evaluating the effect of the type and concentration of potential ions on wettability alteration and IFT. The design was performed at three levels of total dissolved solids (TDS), i.e., 2000, 5000 and 7000 ppm. Three criteria were considered to choose the total salinity of the imbibition brine:

1. This is the salinity range in which effective results of wettability alteration in carbonate rocks have been reported in the literature (Al-Rossies et al. 2010; Rashid et al. 2015).

2. In this salinity range, oil/brine IFT reduction is not intense (Lashkarbolooki et al. 2014a, b).

3. This is the salinity range in which a reduction in $\mathrm{CO}_{2}$ solubility in water is not severe. As the $\mathrm{CO}_{2}$ solubility in water reduces, the strength of $\mathrm{CW}$ for wettability alteration, oil swelling, and viscosity reduction reduces (Riazi et al. 2009). At higher total salinities, the carbon dioxide solubility reduces significantly (Weiss 1974; Scharlin 1996).

The conditions of 12 designed experiments with TDS of $7000 \mathrm{ppm}$ are shown in Table 5. For the other two total salinities of 5000 and 2000 ppm, the experiments are similar and are not shown for the sake of brevity.
Table 5 Experimental conditions designed by Design Expert 7.0, showing the concentration of different ions in the synthetic brine at a total salinity of $7000 \mathrm{ppm}$

\begin{tabular}{llllll}
\hline $\begin{array}{l}\text { Solution } \\
\text { number }\end{array}$ & \multicolumn{5}{l}{ Ion concentration, $\mathrm{mol} / \mathrm{L}$} \\
\cline { 2 - 6 } & $\mathrm{SO}_{4}^{2-}$ & $\mathrm{Ca}^{2+}$ & $\mathrm{Mg}^{2+}$ & $\mathrm{Na}^{+}$ & $\mathrm{Cl}^{-}$ \\
\hline 1 & 0.000 & 0.000 & 0.000 & 0.120 & 0.120 \\
2 & 0.000 & 0.014 & 0.000 & 0.094 & 0.121 \\
3 & 0.000 & 0.009 & 0.029 & 0.055 & 0.131 \\
4 & 0.000 & 0.025 & 0.001 & 0.073 & 0.122 \\
5 & 0.047 & 0.000 & 0.000 & 0.100 & 0.005 \\
6 & 0.015 & 0.000 & 0.019 & 0.082 & 0.089 \\
7 & 0.014 & 0.000 & 0.051 & 0.037 & 0.104 \\
8 & 0.020 & 0.011 & 0.000 & 0.090 & 0.072 \\
9 & 0.000 & 0.000 & 0.063 & 0.006 & 0.146 \\
10 & 0.023 & 0.005 & 0.032 & 0.048 & 0.076 \\
11 & 0.029 & 0.024 & 0.000 & 0.061 & 0.051 \\
12 & 0.001 & 0.021 & 0.046 & 0.004 & 0.137 \\
\hline
\end{tabular}

\subsubsection{IFT and contact angle measurements}

Contact angle measurements were performed using several thin sections cut from eight core plugs after these thin sections were completely saturated with the synthetic formation brine. To assess the extent of wettability alteration, first, the contact angle of a clean brine-saturated thin section (i.e., $\theta_{\text {initial }}$ ) was measured using a drop shape analysis device (DSA-100, Krüss, Germany). The measurement was repeated four times at different positions on the thin section using distilled water and crude oil as the fluid pair. The average of four measured contact angles was reported as the initial contact angle.

Then, all thin sections were put in crude oil and aged for $1000 \mathrm{~h}$ at $158{ }^{\circ} \mathrm{F}$ to reach completely oil-wet conditions (Seyyedi and Sohrabi 2015; Seyyedi et al. 2015). After aging treatment, to ensure the accurate measurement of the contact 
angle on oil-wet thin sections, the bulk oil was removed from the surface of all thin sections by centrifuging at $3000 \mathrm{rpm}$ for 20 min using a centrifuge tube filled with distilled water. Then, the contact angle measurement was conducted four times and the average was reported as $\theta_{\text {aged }}$. Figure 2 shows pictures of the aged and unaged thin sections.

In the next step, the oil drops, which were previously used to measure contact angle, were removed from the rock surface by centrifuging thin sections with the same procedure employed before. Each aged sample was then soaked for $55 \mathrm{~h}$ in different brine solutions with the compositions shown in Table 5 ; then, the altered contact angle $\left(\theta_{\text {altered }}\right)$ was measured using the desired brine solution and crude oil as the fluid pair. Finally, to determine the extent of wettability alteration, the wettability alteration index (WAI) was calculated for each solution using Eq. (1) (Sheng 2013):

$\mathrm{WAI}=\frac{\theta_{\text {aged }}-\theta_{\text {altered }}}{\theta_{\text {aged }}-\theta_{\text {initial }}}$

In addition, a series of IFT tests were performed using the DSA-100 device to evaluate the interfacial tension between oil and different brine solutions with a precision of $0.01 \mathrm{mN} / \mathrm{m}$. Solutions that give maximum wettability alteration and minimum IFT reduction could be proper candidates for spontaneous imbibition experiments. For water to initiate imbibing into the rock spontaneously, it is necessary to alter the rock wettability to water-wet conditions to get positive capillary forces. On the other hand, IFT should not decrease severely to have enough capillary force and as a result powerful spontaneous imbibition. Therefore, in this study, the solution with the highest WAI and IFT value (called SH solution) was chosen as the solution that was expected to have the best return in spontaneous imbibition experiments. Also, another solution with almost the same IFT value but with a much lower WAI value (named SL solution) was chosen to compare its performance with the $\mathrm{SH}$ solution in spontaneous imbibition experiments.

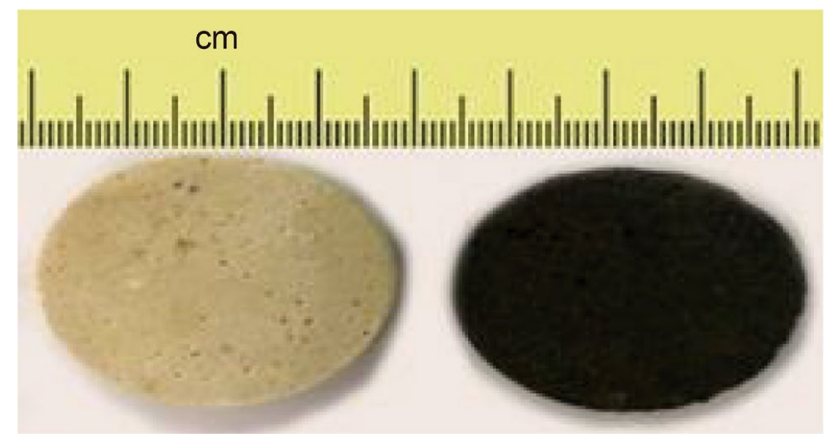

Fig. 2 Photographs of unaged (left) and aged (right) thin sections

\subsubsection{Ambient pressure spontaneous imbibition of brine}

After the core samples were cleaned, their pore volume, porosity, and absolute permeability were measured. Then, the core plugs were completely saturated with synthetic formation brine (Table 2), and the initial water saturation $\left(S_{\mathrm{wi}}\right)$ condition was established by injecting crude oil into the brine-saturated cores. After that, ambient pressure spontaneous imbibition experiments were performed at $104^{\circ} \mathrm{F}$ using conventional spontaneous imbibition cells made of glass. The reason for choosing this temperature was to keep the experimental conditions near ambient and also to ensure that a constant temperature is maintained by an oven during the imbibition experiments.

The imbibition brines used in these experiments included three solutions: (a) the solution with the maximum wettability alteration toward water wetness and with the small IFT reduction, (b) the solution with approximately equal IFT to the IFT of the solution in part (a) but with lower ability in wettability alteration (lower WAI), and (c) Persian Gulf (PG) water.

\subsubsection{High-pressure spontaneous imbibition of CW}

High-pressure spontaneous imbibition experiments were performed to evaluate the effects of dissolved $\mathrm{CO}_{2}$ on the imbibition rate of water and also the effects of smart water on imbibition of $\mathrm{CW}$. Imbibition brine solutions were selected based on the IFT and contact angle results with the details explained in the next section, and then the carbonated form of these brine solutions was also used as imbibition brine in the high-pressure spontaneous imbibition experiments.

Carbonated water solutions used in these experiments were prepared by mixing brines with different compositions and $\mathrm{CO}_{2}$ with purity of $99.9 \%$ in a rocking cell apparatus at $104{ }^{\circ} \mathrm{F}$ and 2000 psi. To reach equilibrium conditions, first the brine solution was transferred into the rocking cell and then $\mathrm{CO}_{2}$ gas was injected into the cell to attain the desired pressure by making a gas cap at the top of the solution. Thereafter, the rocking cell was rotated to dissolve the gas in the brine. Upon dissolving carbon dioxide, the cell pressure reduces. Therefore, $\mathrm{CO}_{2}$ gas was injected into the cell at a very low rate until reaching the desired pressure again. This process was repeated several times within at least $48 \mathrm{~h}$ until no pressure drop occurred (which was the sign of equilibrium conditions). The solubility of $\mathrm{CO}_{2}$ in water is a function of pressure, temperature, and salinity. It increases with increasing pressure, decreasing temperature, and decreasing salinity. Figure 3 shows $\mathrm{CO}_{2}$ solubility curves in freshwater at different temperatures (Crawford et al. 1963; Holm 1963; Jarrell et al. 2002) which could be adjusted to the salinity of the brine using Fig. 4 (Johnson et al. 1952; Martin 1951; Chang et al. 1996; Jarrell et al. 2002). The performance of 


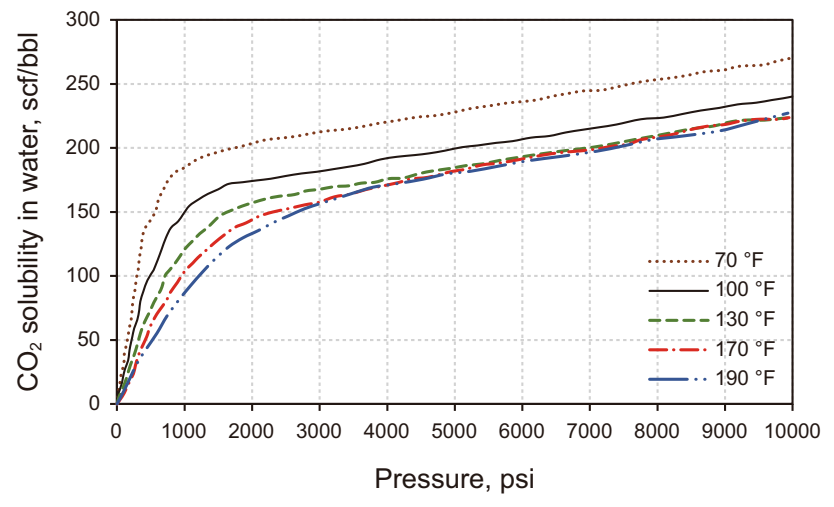

Fig. $3 \mathrm{CO}_{2}$ solubility in freshwater at different pressures and temperatures (Crawford et al. 1963; Holm 1963; Jarrell et al. 2002)

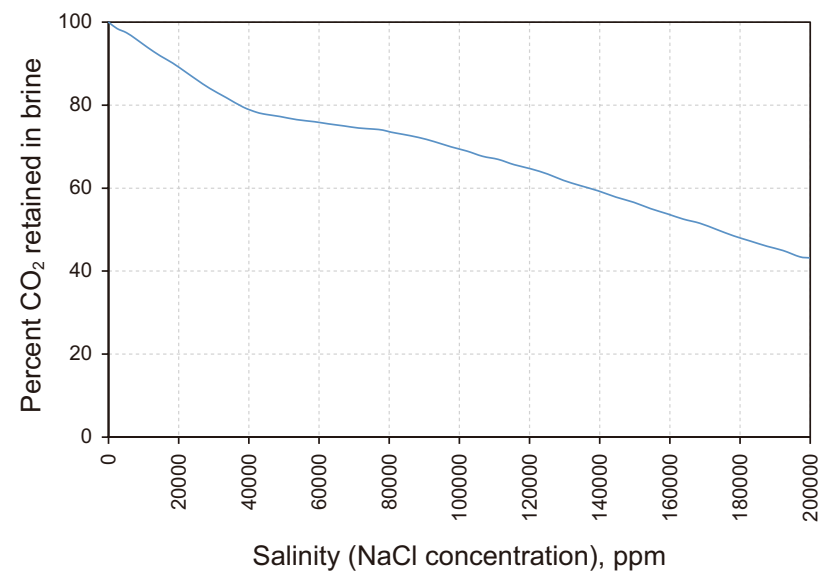

Fig. $4 \mathrm{CO}_{2}$ solubility-adjusting curve. The $\mathrm{CO}_{2}$ solubility is adjusted based on brine salinity (Martin 1951; Johnson et al. 1952; Chang et al. 1996; Jarrell et al. 2002) spontaneous imbibition of $\mathrm{CW}$ is enhanced by increasing the amount of dissolved $\mathrm{CO}_{2}$ (Riazi 2011; Sohrabi et al. 2011); thus, the imbibition of $\mathrm{CW}$ is expected to improve with increasing pressure, decreasing temperature, and decreasing brine salinity. As shown in Fig. 3, the $\mathrm{CO}_{2}$ solubility sharply increases with pressure up to about 2000 psi; however, above this pressure, the solubility change is not very significant. Therefore, in this study, the high-pressure spontaneous imbibition experiments were conducted at 2000 psi, low salinities (i.e., the total salinity under $10,000 \mathrm{ppm}$ ) and temperature of $104{ }^{\circ} \mathrm{F}$ as the optimum conditions based on $\mathrm{CO}_{2}$ solubility and operational considerations.

The conventional glass spontaneous imbibition cells that were used for atmospheric pressure tests are not suitable for high-pressure spontaneous imbibition tests. Therefore, a special setup was designed to conduct high-pressure spontaneous imbibition experiments. As shown in Fig. 5, the setup consists of a high-pressure injecting pump, a cylinder for keeping and injecting CW solutions, an oven for providing constant temperature during spontaneous imbibition tests, a high-pressure imbibition cell to ensure that the imbibition occurs spontaneously by providing equal pressure all around the core plug, a back-pressure regulator, and a fluid separator.

For high-pressure spontaneous imbibition experiments, first the core plug was placed in the imbibition cell and the back-pressure regulator (BPR) was set at 2000 psi. Then, the imbibing brine was injected from the bottom of the cell until the first droplets of water came out of the BPR output to ensure that the imbibition cell was completely filled with the imbibing brine. The imbibition cell was designed so there is a space between the inner part of the imbibition cell and the core plug, and therefore, all surfaces of the core plug were in contact with the brine when the brine was injected into the

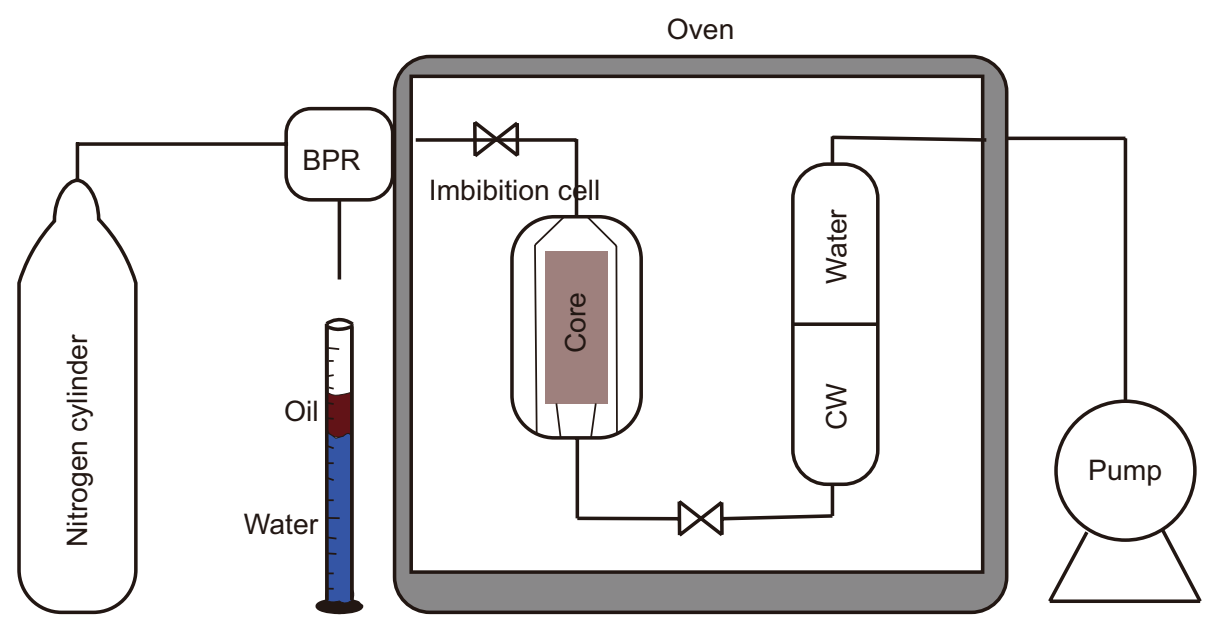

Fig. 5 High-pressure spontaneous imbibition setup 
cell. Due to the existence of this space that acts as a fracture around a matrix block, there would be no resistance to the injecting flow, and therefore the pressure gradient that can lead to pushing the oil out from the core will not be applied to the rock. At the time of sampling, the imbibing brine with the volume of the space between the imbibition cell and the core plug was injected into the cell and the outlet fluids were collected. After removing the gas from the collected fluids, oil and water were separated, and the amount of recovered oil was measured. Taking samples was stopped when no oil production was observed after at least $100 \mathrm{~h}$ of starting the test.

\section{Results and discussion}

\subsection{Results of contact angle and IFT measurements}

The objective of this step was: (1) to find a brine solution with maximum wettability alteration capacity, (2) to find a solution with approximately equal solution/oil IFT, like the one in the first step, but with lower wettability alteration ability, and (3) to compare the performance of both solutions in spontaneous imbibition experiments.

Figure 6 and Table 6 show the measured IFTs for all 36 brine solutions. With respect to IFT results, it was found that for all brines, at the salinity range studied here, upon increasing the total solution salinity, the oil/brine IFT reduces. Moreover, at each salinity level, with increasing concentration of divalent ions in the aqueous phase, the brine/oil IFT decreases. This IFT reduction could be attributed to the higher tendency of natural surfactant molecules (such as asphaltenes and resins) in crude oil to transfer into the oil/brine interface at higher salinities and also at higher

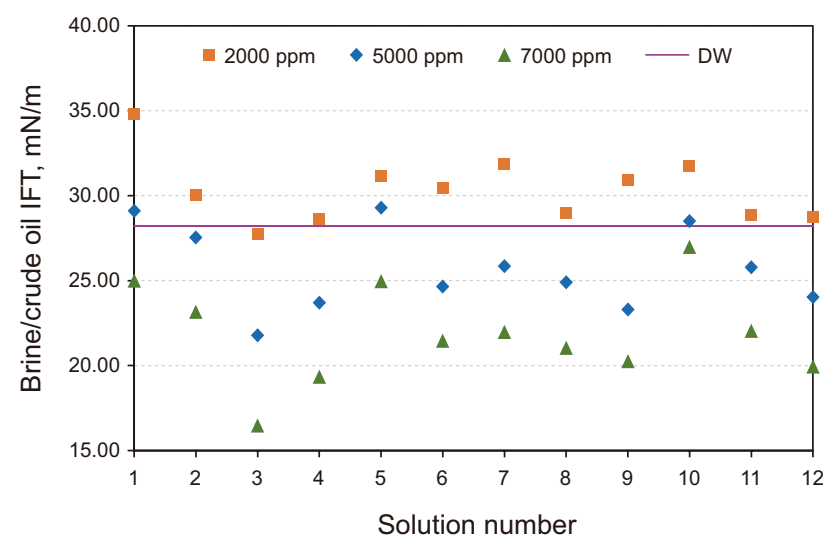

Fig. 6 Measured brine/crude oil IFTs for solutions with different concentrations and salinities. DW line is the measured IFT for distilled water/crude oil shown for comparison concentrations of divalent ions when the total salinity is constant (Lashkarbolooki et al. 2014a, b).

Figure 7 shows the calculated WAIs using Eq. (1) based on the measured contact angles for all 36 brine solutions. To discern the individual effect of TDS and brine composition on WAI, a factorial analysis of variance was performed. $p$ values of $6.01 \times 10^{-13}$ and $4.42 \times 10^{-4}$ were obtained for the solution type and TDS, respectively. The small $p$ values reveal that both factors significantly affect WAI. However, the results of this analysis indicate that the solution type (brine composition) is more effective in altering the rock wettability compared to TDS. Moreover, at almost all of the levels of the total salinity, solutions 7, 9, 10, and 12 with a maximum concentration of potential determining ions (i.e., $\mathrm{Ca}^{2+}, \mathrm{Mg}^{2+}$, and $\mathrm{SO}_{4}{ }^{2-}$ ) showed the highest wettability alteration. Previous studies showed potential determining ions are capable of desorbing the adsorbed polar components (i.e., carboxylates) from the rock surface (Strand et al. 2003, 2008; Zhang et al. 2007; Karimi et al. 2015). Among these four solutions, solution 10 with a maximum concentration of $\mathrm{SO}_{4}{ }^{2-}$ resulted in the best wettability alteration. Adsorption of negatively charged sulfate ions on the positively charged dolomite surface reduces the positive charge of the dolomite. Therefore, magnesium and calcium ions can get closer to the rock surface and carboxylate groups are desorbed more easily by these ions (RezaeiDoust et al. 2009; Fathi et al. 2012; Rashid et al. 2015).

Two solutions with approximately equal crude oil/brine IFT but with a significant difference in wettability alteration index were selected as the imbibition brines. Among the solutions with a salinity of $5000 \mathrm{ppm}$, solution 10 with a WAI of 0.93 and solution/crude oil IFT of $28.50 \mathrm{mN} / \mathrm{m}$ was selected (this solution is called $\mathrm{SH}$ ), and from the solutions with a salinity of $2000 \mathrm{ppm}$, solution 8 with WAI of 0.52 and solution/crude oil IFT of $28.99 \mathrm{mN} / \mathrm{m}$ was chosen (this solution is called SL).

\subsection{Effect of wettability alteration on imbibition rate and oil recovery}

A spontaneous imbibition experiment for seawater showed a relatively low ultimate oil recovery factor [2.6\% OOIP (original oil in place)] in the aged core, as shown in Fig. 8 (the green curve). This could be related to the relatively low potential of seawater for altering the wettability of oil-wet dolomite rock. Looking at the data of contact angles and IFT shown in Table 6 , it can be seen that seawater changed the contact angle from $143^{\circ}$ to $112^{\circ}$ and the measured IFT for seawater/crude oil was $34.20 \mathrm{mN} / \mathrm{m}$. These results show that seawater was not successful in altering wettability of the core and promoting the imbibition rate (i.e., the apparent slope of oil recovery curve). It should be noted that since sampling of the outlet fluid from the imbibition cell is 
Table 6 Measured contact angles, calculated WAI, and measured IFTs for solutions with different salinities. Contact angles and IFTs were measured using crude oil as the drop phase and brine as the bulk phase

\begin{tabular}{|c|c|c|c|c|c|c|}
\hline $\begin{array}{l}\text { Total salinity, } \\
\text { ppm }\end{array}$ & Solution number & $\theta_{\text {initial }}$, degree & $\theta_{\text {aged, }}$ degree & $\theta_{\text {altered }}$, degree & Calculated WAI & $\begin{array}{l}\text { Measured solution/ } \\
\text { crude oil IFT, mN/m }\end{array}$ \\
\hline \multirow[t]{12}{*}{2000} & 2000.1 & $43.6 \pm 1.1$ & $144.2 \pm 1.2$ & $133.4 \pm 0.9$ & 0.11 & 34.78 \\
\hline & 2000.2 & $46.8 \pm 1.2$ & $143.1 \pm 1.3$ & $116.6 \pm 0.8$ & 0.18 & 30.04 \\
\hline & 2000.3 & $45.2 \pm 0.9$ & $146.5 \pm 1.1$ & $78.3 \pm 1.0$ & 0.39 & 27.74 \\
\hline & 2000.4 & $45.0 \pm 1.4$ & $140.4 \pm 0.7$ & $105.6 \pm 1.1$ & 0.30 & 28.64 \\
\hline & 2000.5 & $47.6 \pm 1.2$ & $141.3 \pm 1.2$ & $121.3 \pm 1.2$ & 0.15 & 31.15 \\
\hline & 2000.6 & $46.5 \pm 1.0$ & $141.2 \pm 1.3$ & $87.9 \pm 1.0$ & 0.40 & 30.48 \\
\hline & 2000.7 & $46.7 \pm 1.3$ & $143.5 \pm 1.0$ & $58.2 \pm 0.6$ & 0.78 & 31.84 \\
\hline & 2000.8 & $46.4 \pm 1.1$ & $139.8 \pm 0.9$ & $89.0 \pm 1.0$ & 0.52 & 28.99 \\
\hline & 2000.9 & $45.8 \pm 1.4$ & $139.9 \pm 0.6$ & $55.6 \pm 0.8$ & 0.67 & 30.93 \\
\hline & 2000.10 & $47.5 \pm 0.9$ & $142.5 \pm 1.1$ & $54.3 \pm 0.7$ & 0.84 & 31.75 \\
\hline & 2000.11 & $45.0 \pm 1.1$ & $143.9 \pm 1.0$ & $76.3 \pm 1.1$ & 0.46 & 28.86 \\
\hline & 2000.12 & $47.6 \pm 1.3$ & $142.6 \pm 0.8$ & $67.6 \pm 0.6$ & 0.69 & 28.74 \\
\hline \multirow[t]{12}{*}{5000} & 5000.1 & $47.9 \pm 1.1$ & $145.3 \pm 1.2$ & $132.9 \pm 0.8$ & 0.13 & 29.10 \\
\hline & 5000.2 & $46.9 \pm 1.2$ & $145.6 \pm 1.4$ & $118.5 \pm 1.0$ & 0.27 & 27.53 \\
\hline & 5000.3 & $47.3 \pm 1.2$ & $141.2 \pm 0.9$ & $78.0 \pm 1.2$ & 0.67 & 21.79 \\
\hline & 5000.4 & $45.5 \pm 1.4$ & $141.8 \pm 0.9$ & $106.7 \pm 1.1$ & 0.36 & 23.71 \\
\hline & 5000.5 & $43.8 \pm 1.0$ & $144.1 \pm 1.1$ & $122.6 \pm 1.3$ & 0.21 & 29.28 \\
\hline & 5000.6 & $45.1 \pm 0.5$ & $141.2 \pm 0.7$ & $87.1 \pm 0.7$ & 0.56 & 24.65 \\
\hline & 5000.7 & $48.1 \pm 1.2$ & $140.5 \pm 0.8$ & $59.1 \pm 0.9$ & 0.88 & 25.85 \\
\hline & 5000.8 & $45.3 \pm 1.5$ & $146.6 \pm 1.2$ & $91.5 \pm 0.8$ & 0.54 & 24.90 \\
\hline & 5000.9 & $47.2 \pm 1.3$ & $143.2 \pm 1.1$ & $57.2 \pm 0.9$ & 0.90 & 23.30 \\
\hline & 5000.10 & $46.2 \pm 1.1$ & $143.3 \pm 1.0$ & $53.2 \pm 0.7$ & 0.93 & 28.50 \\
\hline & 5000.11 & $45.9 \pm 1.0$ & $144.1 \pm 1.3$ & $77.0 \pm 0.9$ & 0.68 & 25.78 \\
\hline & 5000.12 & $43.3 \pm 1.2$ & $139.9 \pm 0.8$ & $63.6 \pm 1.0$ & 0.79 & 24.03 \\
\hline \multirow[t]{12}{*}{7000} & 7000.1 & $46.5 \pm 1.1$ & $144.0 \pm 1.2$ & $132.5 \pm 0.8$ & 0.12 & 25.00 \\
\hline & 7000.2 & $42.8 \pm 1.1$ & $139.3 \pm 0.9$ & $112.8 \pm 1.2$ & 0.29 & 23.17 \\
\hline & 7000.3 & $44.2 \pm 1.0$ & $139.7 \pm 1.0$ & $75.4 \pm 1.0$ & 0.74 & 16.49 \\
\hline & 7000.4 & $43.1 \pm 1.2$ & $143.6 \pm 1.2$ & $107.0 \pm 1.1$ & 0.30 & 19.35 \\
\hline & 7000.5 & $42.4 \pm 1.2$ & $145.0 \pm 1.4$ & $123.1 \pm 1.3$ & 0.23 & 24.97 \\
\hline & 7000.6 & $42.4 \pm 1.1$ & $141.3 \pm 1.2$ & $85.6 \pm 0.9$ & 0.51 & 21.47 \\
\hline & 7000.7 & $43.7 \pm 0.6$ & $143.3 \pm 1.2$ & $55.5 \pm 1.0$ & 0.91 & 21.99 \\
\hline & 7000.8 & $44.1 \pm 1.3$ & $144.2 \pm 1.4$ & $89.8 \pm 1.4$ & 0.45 & 21.06 \\
\hline & 7000.9 & $43.6 \pm 1.0$ & $142.8 \pm 1.3$ & $53.9 \pm 1.2$ & 0.83 & 20.26 \\
\hline & 7000.10 & $43.1 \pm 0.5$ & $146.1 \pm 1.3$ & $50.5 \pm 1.0$ & 0.83 & 26.98 \\
\hline & 7000.11 & $42.1 \pm 1.4$ & $143.5 \pm 0.9$ & $74.2 \pm 1.3$ & 0.58 & 22.05 \\
\hline & 7000.12 & $42.4 \pm 1.3$ & $142.3 \pm 0.9$ & $63.4 \pm 0.8$ & 0.65 & 19.96 \\
\hline
\end{tabular}

Contact angles and IFTs were measured using crude oil as the drop phase and brine as the bulk phase

carried out almost every $24 \mathrm{~h}$ or more, the amount of measured output oil is an average of the oil production within this period and therefore, the actual imbibition rate within this period (the time interval from one sample to another) cannot be measured.

Spontaneous imbibition experiments were then performed for SH, SL, and PG solutions to further evaluate the effect of wettability on spontaneous imbibition. The blue, orange, and green curves in Fig. 8 show the recovery factors of the SH, SL, and PG solutions, respectively. The core plugs used for these spontaneous imbibition experiments were $\mathrm{C}_{1}, \mathrm{C}_{3}$, and $\mathrm{C}_{5}$, respectively (with specifications shown in Table 4). Although the physical properties of these core plugs were almost the same, for the solution with greater WAI more oil recovery and a higher imbibition rate were achieved. These results reveal the importance of the wettability alteration during the spontaneous imbibition process. In other words, for a good spontaneous 


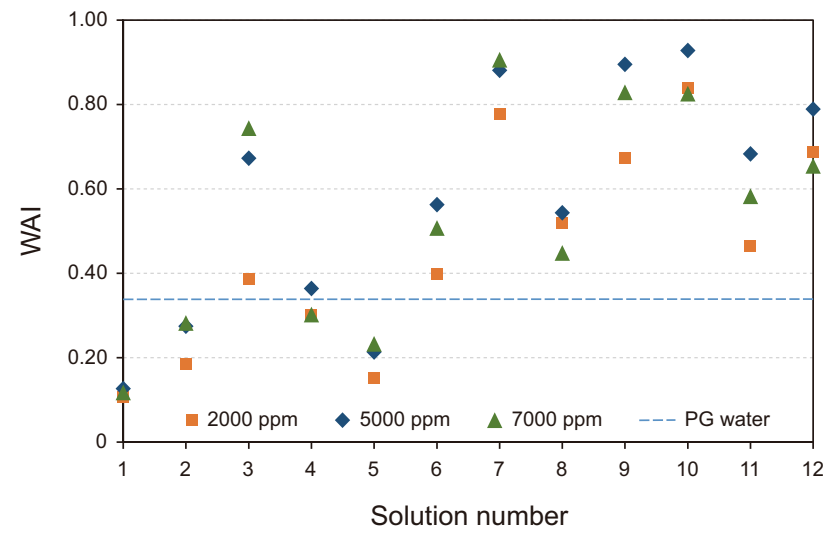

Fig. 7 Calculated wettability alteration index (WAI) for solutions with different compositions and salinities

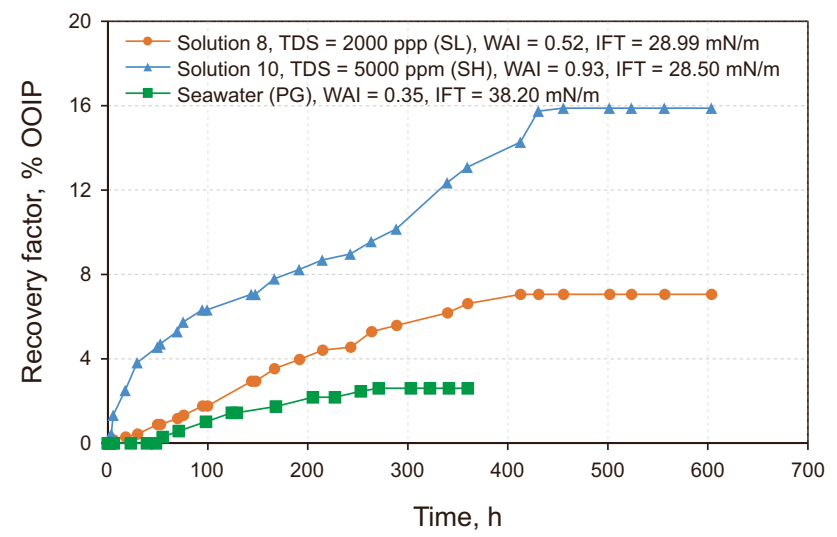

Fig. 8 Effect of brine composition on the spontaneous imbibition recovery

imbibition rate and oil recovery, it is required that imbibition brine has the high potential to change wettability to strongly water-wet conditions.

In general, there are two types of forces that mainly control the spontaneous imbibition of water into the core plug: gravity and capillary forces. At first, when the core plug is completely oil-wet and capillary forces are against the spontaneous imbibition, solutions with higher IFT reduction can decrease the amount of counterproductive forces (capillary forces) and as a result, increase the productive forces (productive force in this situation is gravity force) for spontaneous imbibition. In other words, when we have oil-wet matrix blocks, we need to decrease the IFT to increase oil production due to gravity forces. Therefore, as can be seen in Fig. 8, for SL and SH solutions that can decrease IFT enough when it is in oil-wet conditions, the initiation of production of oil droplets could be observed at early stages. However, for PG which is unable to decrease IFT enough, after about $50 \mathrm{~h}$, when it reaches neutral or water-wet conditions and the capillary forces turn to be productive, the first oil droplet can be seen on the core wall.

\subsection{Spontaneous imbibition of $\mathrm{CO}_{2}$-enriched brines}

In this section, the results of spontaneous imbibition experiments of plain and carbonated water $\left(\mathrm{CO}_{2}\right.$-enriched $)$ solutions were compared. Figure 9 compares the oil recovery results of the first atmospheric spontaneous imbibition experiment and the first high-pressure spontaneous imbibition of carbonated water. These experiments were carried out using core plugs of almost-identical physical properties (cores $\mathrm{C}_{4}$ and $\mathrm{C}_{8}$ with specifications shown in Table 4). In both experiments, the cores had been aged in crude oil for $1000 \mathrm{~h}$ at $158{ }^{\circ} \mathrm{F}$ to allow their wettability to be naturally changed to oil-wet conditions. In both experiments, the spontaneous imbibition was carried out for solution 1 with a salinity of $2000 \mathrm{ppm}$ which consisted only of $\mathrm{Na}^{+}$ and $\mathrm{Cl}^{-}$. In the atmospheric experiment, the solution was in contact with the aged core in a glass imbibition cell for 29 days; however, as shown in the blue line in Fig. 9, no oil production was observed during this time. This result indicates that the $\mathrm{NaCl}$ solution was unable to change the wettability of the strongly oil-wet core; hence, spontaneous imbibition did not take place. In the high-pressure experiment, a carbonated form of the former solution was used as the imbibing brine. After approximately 5 days, oil production started (the brown curve). The results show an oil recovery of about $4 \%$ OOIP after about 18 days. This low oil recovery compared to zero oil recovery of the plain $\mathrm{NaCl}$ solution could be attributed to the ability of $\mathrm{CW}$ to change the carbonate rock wettability from oil-wet to neutral or weakly water-wet conditions through dissolution of carbonate rock which leads to detaching carboxylate groups from the rock surface because of its acidic power (Seyyedi et al. 2015). This provides a positive capillary

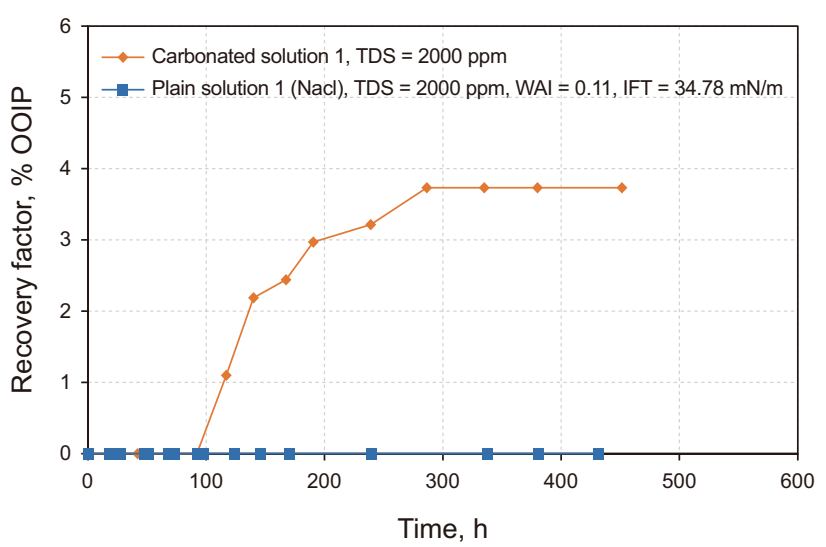

Fig. 9 Spontaneous imbibition recovery curves, the effect of $\mathrm{CW}$ on wettability alteration and spontaneous imbibition 
pressure and lets the $\mathrm{CW}$ imbibe into the core. Addition of $\mathrm{CO}_{2}$ to water would result in an acidic $\mathrm{pH}$ which can be obtained by the following correlation:

$\mathrm{pH} \sim \log \left(10^{-14}+\frac{K_{\mathrm{h}} K_{\mathrm{a} 1}}{K_{\mathrm{H}}} P_{\mathrm{CO}_{2}}\right)^{\frac{1}{2}}$

where $P_{\mathrm{CO}_{2}}$ is the partial pressure of $\mathrm{CO}_{2}, K_{\mathrm{h}}$ is the hydration equilibrium constant, $K_{\mathrm{H}}$ is Henry's constant, and $K_{\mathrm{a} 1}$ is the dissociation constant (i.e., dissociation of carbonic acid into bicarbonate) (Riazi 2011).

Previous studies also show that dissolved $\mathrm{CO}_{2}$, even at low $\mathrm{CO}_{2}$ partial pressure, can reduce the $\mathrm{pH}$ of the fully saturated CW (Crawford et al. 1963; Ross 1982). The pH value of carbonated water at a pressure of $2000 \mathrm{psi}$ and temperature of $104{ }^{\circ} \mathrm{F}$ is estimated to be around 3 according to Eq. (2). This $\mathrm{pH}$ is low enough such that the solution can dissolve minerals of carbonate rocks and also detach carboxylate groups from the rock surface (Seyyedi and Sohrabi 2015; Seyyedi et al. 2015; Abbaszadeh et al. 2016).

In addition, oil swelling and oil viscosity reduction are other mechanisms by which $\mathrm{CW}$ could enhance the oil recovery as a result of $\mathrm{CO}_{2}$ diffusion from the water phase to the oil phase (Riazi et al. 2009, 2011; Seyyedi and Sohrabi 2015).

Figure 10 compares spontaneous imbibition recovery curves of seawater (PG) and carbonated seawater (carbonated PG), which were conducted under high-pressure conditions. The core plugs used for these two experiments $\left(\mathrm{C}_{6}\right.$ and $\mathrm{C}_{9}$ ) were almost similar in terms of physical properties as shown in Table 4. Similar to the results shown in Fig. 7, these curves indicate that the carbonated seawater imbibes more in the oil-wet cores compared to the plain seawater,

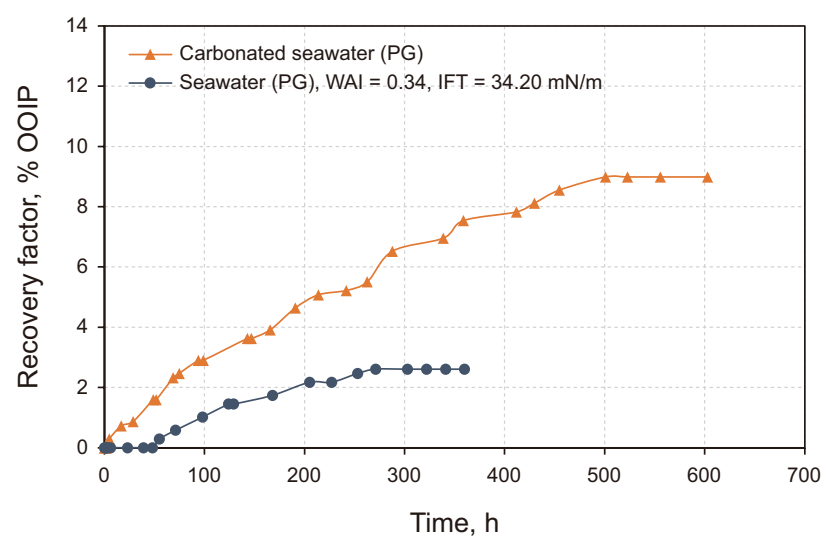

Fig. 10 Spontaneous imbibition recovery curves, the effect of $\mathrm{CW}$ on spontaneous imbibition of seawater showing the positive impacts of $\mathrm{CW}$ including wettability alteration, oil swelling, and oil viscosity reduction.

\subsection{Spontaneous imbibition of carbonated smart water}

In Sect. 3.3, it was shown that the $\mathrm{NaCl}$ solution as imbibition brine has no wettability alteration effect even after a long running time $(400 \mathrm{~h})$. Therefore, after this period, imbibition brine was replaced with SL solution in order to investigate the effect of divalent ions on wettability alteration and oil recovery. As shown in Fig. 11, oil recovery started approximately $20 \mathrm{~h}$ after this replacement (the purple curve). Adding potential determining ions (i.e., $\mathrm{Ca}^{2+}$ and $\mathrm{SO}_{4}{ }^{2-}$ ) to the system leads to wettability alteration toward the water-wet conditions by detaching the negatively charged oil components from the rock surface and consequently, after a while water spontaneously imbibed into the core. $\mathrm{SO}_{4}{ }^{2-}$ ions tend to adsorb on the positively charged dolomite surface resulting in a decrease in the positive charge of the rock surface. By lowering the level of the positive charge of the rock, $\mathrm{Ca}^{2+}$ ions tend to get closer to the surface and consequently, detach the negatively charged carboxylate groups more easily (Strand et al. 2006; Fathi et al. 2010, 2011; Shariatpanahi et al. 2016).

In the experiments with results shown in Fig. 9, after reaching a plateau in the oil recovery curve of the carbonated $\mathrm{NaCl}$ solution (the orange curve), without changing the core or any other experimental conditions, carbonated brine of the SL solution was injected into the imbibition cell from the bottom to replace the former solution. As shown in Fig. 11 (the green curve), after approximately $110 \mathrm{~h}$, oil production started again, and the final oil production reached $13.5 \%$. This result emphasizes the synergic effect of the potential determining ions and the effect of the dissolution mechanism

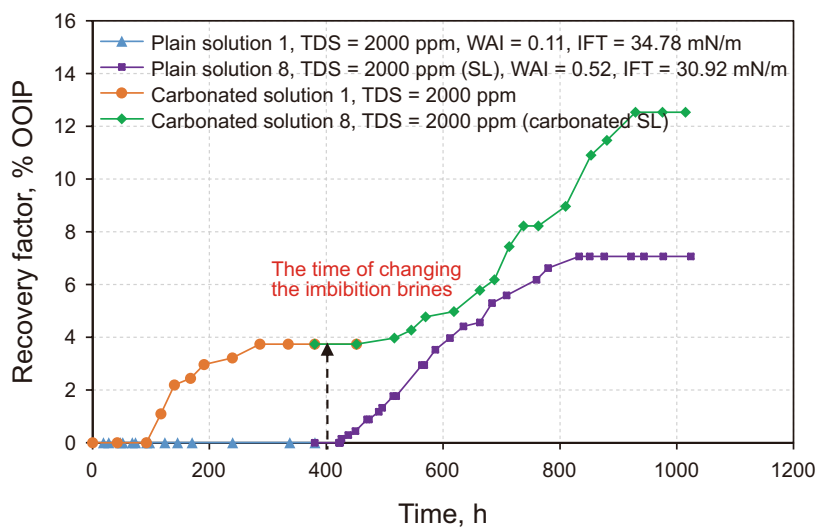

Fig. 11 Spontaneous imbibition recovery curves, effect of carbonated water and divalent ions on spontaneous imbibition in the aged carbonate cores 


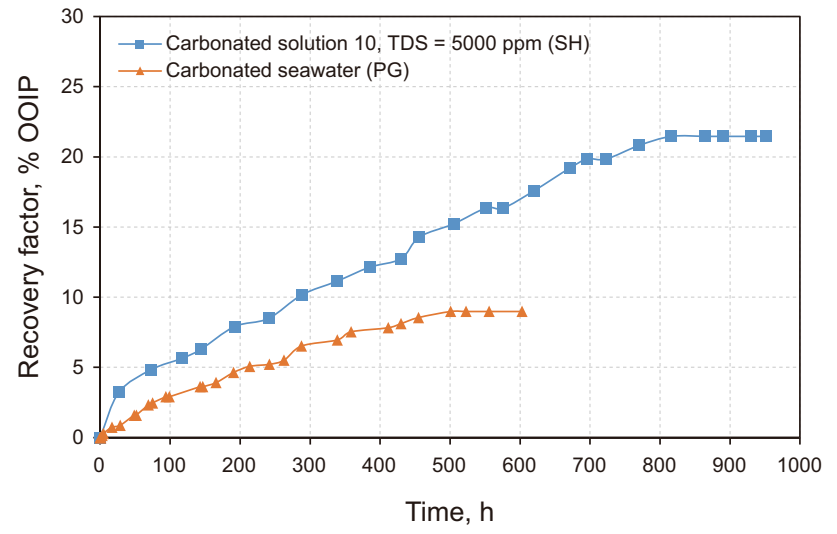

Fig. 12 Spontaneous imbibition recovery curves, the effect of salinity and brine composition on oil recovery and spontaneous imbibition rate

of CW on wettability alteration (Seyyedi and Sohrabi 2015; Seyyedi et al. 2015; Vaz et al. 2017) which can enhance the imbibition rate and also oil recovery through accelerating and intensifying the process of wettability alteration of the carbonate oil-wet rock to water-wet conditions. Therefore, the positive capillary pressure caused spontaneous imbibition of water into the core and resulted in an additional oil recovery. As can be seen from the $\mathrm{CW}$ recovery curve shown in Fig. 11, unlike the plain brine, oil production did not start immediately after the replacement of imbibition brine with smart water. This could be related to the amount and distribution of the residual oil saturation at the beginning of the second stage of the spontaneous imbibition experiment (Viksund et al. 1998; Zhou et al. 2000). In the case of plain brine, because there was no oil recovery during the first stage, oil recovery started faster. However, for the case of $\mathrm{CW}$, since part of CW should have passed through swept zones of the core plug at the beginning of the second stage, it took a longer time to lead to oil recovery.

Another example of the positive impact of smart water to improve spontaneous imbibition of $\mathrm{CW}$ can be seen in Fig. 12 which compares the results of oil recovery for the carbonated SH solution and the carbonated seawater. The faster and higher oil recovery for the carbonated SH confirms the impact of the modification of imbibition brine salinity and composition on wettability alteration and oil recovery.

\section{Conclusions}

We explored the possibility of improving brine imbibition rates in dolomite core plugs by altering the rock wettability using carbonated smart brines. The following conclusions can be drawn from this experimental study:
1. The most important mechanism that controls the success of the spontaneous imbibition process in oil-wet rocks is wettability alteration. As the strength of the imbibition brine for wettability alteration toward more water-wet condition increases, the amount of imbibed water into the rock and consequently oil recovery would increase.

2. Using solutions which contain divalent ions (i.e., $\mathrm{Mg}^{2+}$, $\mathrm{Ca}^{2+}, \mathrm{SO}_{4}{ }^{2-}$ ) with customized salinity and concentrations, it is possible to increase the wettability alteration strength of imbibing brine. This enhances the amount of imbibing water during spontaneous imbibition of both plain brine and carbonated brine.

3. Carbonation at high pressures provides high acidic power to the imbibing water which can accelerate the wettability alteration through the dissolution of surface rock and oil aggregates, leading to reinforcement of spontaneous imbibition.

4. When comparing spontaneous imbibition of smart water and carbonated smart water, it is concluded that although high-pressure carbonation slightly reduces the imbibition rate through IFT reduction, the final oil recovery is significantly higher, because of the incremental power of the acidic brine in wettability alteration, oil swelling, and oil viscosity reduction.

Acknowledgements The authors would like to acknowledge the financial support from National Iranian South Oil Company (NISOC). We also thank Petroazma Knowledge-Based Oil Company for its contribution in assembling the experimental rig. Proofreading of the article by Dr. H. Parsaei is hereby appreciated. The co-operation of Mr. M. Abbaszadeh, Ms. S. Shojaei, Mr. B. Dehdari, and Ms. D. Panahpouri during this study is also acknowledged.

Open Access This article is distributed under the terms of the Creative Commons Attribution 4.0 International License (http://creativeco mmons.org/licenses/by/4.0/), which permits unrestricted use, distribution, and reproduction in any medium, provided you give appropriate credit to the original author(s) and the source, provide a link to the Creative Commons license, and indicate if changes were made.

\section{References}

Abbaszadeh M, Nasiri M, Riazi M. Experimental investigation of the impact of rock dissolution on carbonate rock properties in the presence of carbonated water. Environ Earth Sci. 2016;75(9):791. https://doi.org/10.1007/s12665-016-5624-3.

Al-Rossies AAS, Al-Anazi BD, Paiaman AM. Effect of pH-values on the contact angle and interfacial tension. NAFTA. 2010;61(4):181-6.

Babadagli T. Evaluation of EOR methods for heavy-oil recovery in naturally fractured reservoirs. J Pet Sci Eng. 2003;37(1-2):25-37. https://doi.org/10.1016/S0920-4105(02)00309-1.

Bourbiaux BJ, Kalaydjian FJ. Experimental study of cocurrent and countercurrent flows in natural porous media. SPE Reserv Eng. 1990;5(03):361-8. https://doi.org/10.2118/18283-PA. 
Chang YB, Coats BK, Nolen JS. A compositional model for $\mathrm{CO}_{2}$ floods including $\mathrm{CO}_{2}$ solubility in water. In: Permian basin oil and gas recovery conference, Society of Petroleum Engineers, March 27-29, Midland, TX; 1996. https://doi.org/10.2118/35164-MS.

Crawford HR, Neill GH, Bucy BJ, Crawford PB. Carbon dioxide-a multipurpose additive for effective well stimulation. J Pet Technol. 1963;15(03):237-42. https://doi.org/10.2118/571-PA.

Fathi SJ, Austad T, Strand S. "Smart water" as a wettability modifier in chalk: the effect of salinity and ionic composition. Energy Fuels. 2010;24(4):2514-9. https://doi.org/10.1021/ef901304m.

Fathi SJ, Austad T, Strand S. Water-based enhanced oil recovery (EOR) by "smart water" in carbonate reservoirs. In: SPE EOR conference at oil and gas west Asia, April 16-18, Muscat, Oman; 2012. https ://doi.org/10.1021/ef201019k.

Fjelde I, Aasen S, Zuta J. Improvement of spontaneous imbibition in carbonate rocks by $\mathrm{CO}_{2}$-saturated brine. In: 16th European symposium on improved oil recovery, April 12-14, Cambridge, UK; 2011. https://doi.org/10.3997/2214-4609.201404766.

Grape SG. Imbibition flooding with $\mathrm{CO}_{2}$-enriched water. M.Sc. dissertation. Texas A\&M University; 1990.

Guo B, Schechter DS, Baker RO. An integrated study of imbibition waterflooding in the naturally fractured Spraberry. In: SPE Permian basin oil and gas recovery conference, March 23-26, Midland, TX; 1998. https://doi.org/10.2118/39801-MS.

Haugen $\AA$. Fluid flow in fractured carbonates: wettability effects and enhanced oil recovery. Doctoral dissertation, University of Bergen; 2010.

Hirasaki G, Zhang DL. Surface chemistry of oil recovery from fractured, oil-wet, carbonate formations. SPE J. 2004;9(02):151-62. https://doi.org/10.2118/88365-PA.

Holm LW. $\mathrm{CO}_{2}$ slug and carbonated water oil recovery processes. Producers Mon. 1963;27(9):6-8.

Jarrell PM, Fox CE, Stein MH, Webb SL. Practical aspects of $\mathrm{CO}_{2}$ flooding. Richardson, TX: Society of Petroleum Engineers; 2002.

Johnson WE, Macfarlane RM, Breston JN. Changes in physical properties of Bradford crude oil when contacted with $\mathrm{CO}_{2}$ and carbonated water. Producers Mon. 1952;16(11):16-21.

Karimi M, Al-Maamari RS, Ayatollahi S, Mehranbod N. Mechanistic study of wettability alteration of oil-wet calcite: the effect of magnesium ions in the presence and absence of cationic surfactant. Colloids Surf A. 2015;482:403-15. https://doi.org/10.1016/j.colsu rfa.2015.07.001.

Lashkarbolooki M, Ayatollahi S, Riazi M. Effect of salinity, resin, and asphaltene on the surface properties of acidic crude oil/smart water/rock system. Energy Fuels. 2014a;28(11):6820-9. https:// doi.org/10.1021/ef5015692.

Lashkarbolooki M, Ayatollahi S, Riazi M. The impacts of aqueous ions on interfacial tension and wettability of an asphaltenic-acidic crude oil reservoir during smart water injection. J Chem Eng Data. 2014b;59(11):3624-34. https://doi.org/10.1021/je500730e.

Martin JW. Additional oil production through flooding with carbonated water. Prod Mon. 1951;15(7):18-22.

Manshad AK, Olad M, Taghipour SA, Nowrouzi I, Mohammadi AH. Effects of water soluble ions on interfacial tension (IFT) between oil and brine in smart and carbonated smart water injection process in oil reservoirs. J Mol Liq. 2016;223:987-93. https://doi. org/10.1016/j.molliq.2016.08.089.

Meng Z, Yang SL, Cui Y, Zhong ZY, Liang CG, Wang L, Qian K, Ma QZ, Wang JR. Enhancement of the imbibition recovery by surfactants in tight oil reservoirs. Pet Sci. 2018;15(4):783-93. https ://doi.org/10.1007/s12182-018-0253-y.

Narr W, Schechter DS, Thompson LB. Naturally fractured reservoir characterization. Richardson, Texas: Society of Petroleum Engineers; 2006.
Nelson R. Geologic analysis of naturally fractured reservoirs. Amsterdam: Elsevier; 2001. https://doi.org/10.1016/B978-0884153177/50004-X.

Oelkers EH, Gislason SR, Matter J. Mineral carbonation of $\mathrm{CO}_{2}$. Elements. 2008;4(5):333-7. https://doi.org/10.2113/gselements 4.5.333.

Pal S, Mushtaq M, Banat F, Al Sumaiti AM. Review of surfactantassisted chemical enhanced oil recovery for carbonate reservoirs: challenges and future perspectives. Pet Sci. 2018;15(1):77-102. https://doi.org/10.1007/s12182-017-0198-6.

Perez JM, Poston SW, Sharif QJ. Carbonated water imbibition flooding: an enhanced oil recovery process for fractured reservoirs. In: SPE/DOE enhanced oil recovery symposium. Society of Petroleum Engineers, April 22-24, Tulsa, OK; 1992. https://doi. org/10.2118/24164-MS.

Rashid S, Mousapour MS, Ayatollahi S, Vossoughi M, Beigy AH. Wettability alteration in carbonates during "Smart Waterflood": underlying mechanisms and the effect of individual ions. Colloids Surf A. 2015;487:142-53. https://doi.org/10.1016/j.colsu rfa.2015.09.067.

RezaeiDoust A, Puntervold T, Strand S, Austad T. Smart water as wettability modifier in carbonate and sandstone: a discussion of similarities/differences in the chemical mechanisms. Energy Fuels. 2009;23(9):4479-85. https://doi.org/10.1021/ef900185q.

Riazi M. Pore scale mechanisms of carbonated water injection in oil reservoirs. Doctoral dissertation, Heriot-Watt University; 2011.

Riazi M, Sohrabi M, Jamiolahmady M. Experimental study of pore-scale mechanisms of carbonated water injection. Transp Porous Media. 2011;86(1):73-86. https://doi.org/10.1007/s1124 2-010-9606-8.

Riazi M, Sohrabi M, Jamiolahmady M, Ireland S. Oil recovery improvement using $\mathrm{CO}_{2}$-enriched water injection. In: EUROPEC/EAGE conference and exhibition, Society of Petroleum Engineers, June 8-11, Amsterdam, The Netherlands; 2009. https ://doi.org/10.2118/121170-MS.

Ross GD. The dissolution effects of carbonated water on oil reservoir carbonates: a study under high pressure carbon dioxide flood conditions. Doctoral dissertation, Heriot-Watt University; 1982.

Sahimi M. Flow and transport in porous media and fractured rock: from classical methods to modern approaches. New York: Wiley; 2011. https://doi.org/10.1002/9783527636693.

Scharlin P, Cargill RW. Carbon dioxide in water and aqueous electrolyte solutions. Oxford: Oxford University Press; 1996.

Seyyedi M, Sohrabi M. Enhancing water imbibition rate and oil recovery by carbonated water in carbonate and sandstone rocks. Energy Fuels. 2015;30(1):285-93. https://doi.org/10.1021/acs.energyfuel s. 5 b02644.

Seyyedi M, Sohrabi M, Farzaneh A. Investigation of rock wettability alteration by carbonated water through contact angle measurements. Energy Fuels. 2015;29(9):5544-53. https://doi. org/10.1021/acs.energyfuels.5b01069.

Shariatpanahi SF, Hopkins P, Aksulu H, Strand S, Puntervold T, Austad T. Water based EOR by wettability alteration in dolomite. Energy Fuels. 2016;30(1):180-7. https://doi.org/10.1021/acs. energyfuels.5b02239.

Sheng J. Enhanced oil recovery field case studies. Oxford: Gulf Professional Publishing; 2013.

Shiraki R, Dunn TL. Experimental study on water-rock interactions during $\mathrm{CO}_{2}$ flooding in the Tensleep Formation, Wyoming, USA. Appl Geochem. 2000;15(3):265-79. https://doi.org/10.1016/ S0883-2927(99)00048-7.

Sohrabi M, Riazi M, Jamiolahmady M, Ireland S, Brown C. Carbonated water injection for oil recovery and $\mathrm{CO}_{2}$ storage. In: Sustainable energy UK conference: meeting the science and engineering challenge, May 13-14, Oxford, UK; 2008. 
Sohrabi M, Riazi M, Jamiolahmady M, Ireland S, Brown C. Mechanisms of oil recovery by carbonated water injection. In: International symposium of the society of core analysts, September 27-30, Noordwijk, The Netherlands; 2009.

Sohrabi M, Riazi M, Jamiolahmady M, Kechut NI, Ireland S, Robertson G. Carbonated water injection (CWI)-a productive way of using $\mathrm{CO}_{2}$ for oil recovery and $\mathrm{CO}_{2}$ storage. Energy Procedia. 2011;4:2192-9. https://doi.org/10.1016/j.egypro.2011.02.106.

Standnes DC, Austad T. Wettability alteration in chalk: 1. Preparation of core material and oil properties. J Pet Sci Eng. 2000a;28(3):11121. https://doi.org/10.1016/S0920-4105(00)00083-8.

Standnes DC, Austad T. Wettability alteration in chalk: 2 Mechanism for wettability alteration from oil-wet to water-wet using surfactants. J Pet Sci Eng. 2000b;28(3):123-43. https://doi. org/10.1016/S0920-4105(00)00084-X.

Strand S, Standnes DC, Austad T. Spontaneous imbibition of aqueous surfactant solutions into neutral to oil-wet carbonate cores: effects of brine salinity and composition. Energy Fuels. 2003;17(5):1133-44. https://doi.org/10.1021/ef030051s.

Strand S, Høgnesen EJ, Austad T. Wettability alteration of carbonates: effects of potential determining ions $\left(\mathrm{Ca}^{2+}\right.$ and $\mathrm{SO}_{4}^{2-)}$ and temperature. Colloids Surf A. 2006;275(1-3):1. https://doi.org/10.1016/j. colsurfa.2005.10.061.

Strand S, Austad T, Puntervold T, Høgnesen EJ, Olsen M, Barstad SM. "Smart water" for oil recovery from fractured limestone: a preliminary study. Energy Fuels. 2008;22(5):3126-33. https://doi. org/10.1021/ef800062n.

Vaz RG, Núñez R, Koroishi ET, de Freitas Filho RD, Trevisan OV. Carbonate rock dissolution under carbonated water injection (CWI). In: International symposium of the society of core analysts, August 27-September 1, Vienna, Austria; 2017.

Viksund BG, Morrow NR, Ma S, Wang W, Graue A. Initial water saturation and oil recovery from chalk and sandstone by spontaneous imbibition. In: International symposium of society of core analysts, September 12-15, The Hague; 1998.

Weiss R. Carbon dioxide in water and seawater: the solubility of a non-ideal gas. Mar Chem. 1974;2(3):203-15. https://doi. org/10.1016/0304-4203(74)90015-2.

Zhang P, Tweheyo MT, Austad T. Wettability alteration and improved oil recovery by spontaneous imbibition of seawater into chalk: impact of the potential determining ions $\mathrm{Ca}^{2+}, \mathrm{Mg}^{2+}$, and $\mathrm{SO}_{4}{ }^{2-}$. Colloids Surf A. 2007;301(1-3):199-208. https://doi. org/10.1016/j.colsurfa.2006.12.058.

Zhou X, Morrow NR, Ma S. Interrelationship of wettability, initial water saturation, aging time, and oil recovery by spontaneous imbibition and waterflooding. SPE J. 2000;5(02):199-207. https ://doi.org/10.2118/62507-PA. 